\title{
PENGARUH CITRA MEREK DAN KUALITAS LAYANAN TERHADAP LOYALITAS PELANGGAN YANG DIMEDIASI OLEH KEPUASAN PELANGGAN MENGGUNAKAN 3SECOND DI KOTA PALU
}

\author{
DIAN HARIANTI \\ ELIMAWATY ROMBE \\ PONIRIN \\ Jurusan Manajemen, Fakultas Ekonomi, Universitas Tadulako \\ Email: hardiantidian179@gmail.com
}

\begin{abstract}
This study aims to study the effect of brand image and service quality on customer satisfaction and customer loyalty. The sample in this study amounted to 100 customers who bought 3Second products in Palu City. Sampling is done by using Purposive Sampling and Accidental Sampling. This research uses path analysis tool to test hypothesis. The results of this study indicate that brand image and service quality have a positive and significant influence on customer loyalty. Meanwhile, customer satisfaction also has a positive and significant impact on customer loyalty. This study also shows that to maintain customer loyalty, 3Second should improve the quality of its services and brand image in order to increase customer satisfaction that will impact on high customer loyalty.
\end{abstract}

Keywords: Brand Image, Service Quality, Customer Loyalty, Customer Satisfaction.

\section{ABSTRAK}

Penelitian ini bertujuan untuk mempelajari pengaruh citra merek dan kualitas layanan terhadap kepuasan pelanggan dan loyalitas pelanggan. Sampel pada penelitian ini berjumlah 100 pelanggan yang membeli produk 3Second di Kota Palu. Pengambilan sampel dilakukan dengan menggunakan Purposive Sampling dan Accidental Sampling. Penelitian ini menggunakan alat analisis path untuk menguji hipotesis. Hasil penelitian ini menunjukan bahwa citra merek dan kualitas layanan memiliki pengaruh positif dan signifikan terhadap loyalitas pelanggan. Sementara itu kepuasan pelanggan juga berpengaruh positif dan signifikan terhadap loyalitas pelanggan. Studi ini juga menunjukkan bahwa untuk menjaga loyalitas pelanggan maka 3Second sebaiknya meningkatkan kualitas layanan dan citra mereknya demi untuk meningkatkan kepuasan pelanggan yang akan berimbas pada tingginya loyalitas pelanggannya.

Kata Kunci: Citra Merek, Kualitas Layanan, Loyalitas Pelanggan, Kepuasan Pelanggan.

\section{PENDAHULUAN}

3Second adalah salah satu distro yang berusaha menjawab kebutuhan dan keinginan masyarakat dengan membuka dua gerai di Kota Palu. Kedua gerai tersebut berlokasi di Jalan Emy Saelan No.42 dan di Palu Grand Mall. Sebagaimana gerai-gerai distro lainnya, 3Second memiliki bangunan fisik yang besar dan menarik baik dari segi interior maupun eksteriorrnya. Berbagai macam produk ditawarkan di distro ini, seperti pakaian, tas, sepatu, serta aksesoris-aksesoris lainnya yang sedang digemari masyarakat. Merek produk yang ditawarkan juga terdiri dari berbagai macam, diantaranya seperti: Greenlight, Moutley dan The Famo. Keseluruhan produk tersebut berasal dari Kota Bandung, sebagai kota utama penghasil pakaian distro. Berikut daftar pengunjung 3Second di Kota Palu.

(Suprapti 2010:285) menyatakan kepuasan pelanggan merupakan sikap keseluruhan yang diperlihatkan oleh pelanggan terhadap suatu produk setelah menggunakan atau mengkomsumsi produk itu. Dilihat dari perspektif manajerial, mempertahankan dan meningkatkan kepuasan pelanggan merupakan hal yang sangat penting. Menurut Irawan (2008:37) kepuasan pelanggan ditentukan oleh persepsi pelanggan atas performance Produk atau jasa dalam memenuhi harapan pelanggan. 
Selain kepuasan pelanggan yang mendukung tercapainya loyalitas pelanggan. Terdapat beberapa keuntungan strategi bagi perusahaan tentang pentingnya mempertahankan loyalitas pelanggan. Imbalan dari loyalitas bersifat jangka panjang dan kumulatif. Jadi, semakin lamanya loyalitas seorang pelanggan, akan semakin besar laba yang dapat diperoleh perusahaan dari seorang pelanggan. Pelanggan yang loyal akan menjadi aset yang sangat bernilai bagi suatu perusahaan atau organisasi. Sementara (Kotler \& Keller, 2009, p. 155) berpendapat bahwa pelanggan yang puas dan loyal (setia) merupakan peluang untuk mendapatkan pelanggan baru. Mempertahankan semua pelanggan yang ada umumnya, akan lebih menguntungkan dibandingkan dengan pergantian pelanggan karena biaya untuk menarik pelanggan baru bisa lima kali lipat dari biaya mempertahankan seorang pelanggan yang sudah ada. Penelitian ini bertujuan untuk mengetahui dan menganalisa: pengaruh citra merek terhadap kepuasan pelanggan 3Second di kota Palu, pengaruh kualitas layanan terhadap kepuasan pelanggan 3Second di kota Palu, dan pengaruh kepuasan pelanggan terhadap loyalitas pelanggan 3Second di kota Palu.

\section{KAJIAN LITERATURE}

\section{Pengertian Citra Merek}

Merek Menurut Aanker dalam Sangadji \& Shopiah (2013) "citra merek adalah seperangkat asosiasi unik yang ingin diciptakan atau dipelihara oleh pemasar. Asosiasi-asosiasi itu menyatakan apa sesungguhnya merek dan apa yang dijanjikan kepada konsumen". Menurut UU Merek N0.15 Tahun 2001 pasal 1 ayat 1 dalam (Tjiptono \& Chandra, 2012, p. 3) merek adalah tanda yang berupa gambar, nama, kata, huruf-huruf, angka-angka susunan warna, atau kombinasi dari unsur-unsur tersebut yang memiliki daya pembeda dan digunakan dalam kegiatan perdagangan barang atau jasa. Perkembangan terakhir menunjukan bahwa bentuk, suara, hologram, dan bahkan aroma juga dimasukan dalam lingkup definisi merek (Tjiptono, 2012, p. 3), Melalui pengetahuan merek yang cukup, konsumen dapat menghemat waktu dan biaya pencarian (searching cost) serta menghindari risiko-risiko yang dapat muncul kemudian, seperti risiko fungsional, finansial, fisik, sosial, dan psikologis. Bagi konsumen, kesan merek yang melekat pada suatu produk disebut citra merek. Fenomena persaingan yang ada dalam era globalisasi akan semakin mengarahkan sistem perekonomian Indonesia ke mekanisme pasar yang memposisikan pemasar untuk selalu mengembangkan dan merebut market share (pangsa pasar). Salah satu aset untuk mencapai keadaan tersebut adalah brand (merek).

Sulistian (2011, p. 32) mendefinisikan citra merek sebagai seperangkat keyakinan, ide, dan kesan yang dimiliki oleh seseorang terhadap suatu merek, karena itu sikap dan tindakan konsumen terhadap suatu merek sangat ditentukan oleh citra merek tersebut. Citra merek merupakan syarat dari merek yang kuat. Simamora dalam Sulistian $(2011$, p. 33), mengatakan citra adalah persepsi yang relatif konsisten dalam jangka waktu panjang. Sehingga tidak mudah untuk membentuk citra, citra sekali terbentuk akan sulit untuk mengubahnya. Citra yang dibentuk harus jelas dan memiliki keunggulan bila dibandingkan dengan pesaingnya, saat perbedaan dan keunggulan merek dihadapkan dengan merek lain. Komponen citra merek (brand image) terdiri atas tiga bagian, yaitu:

1) Citra pembuat (corporate image), yaitu sekumpulan asosiasi yang dipersepsikan konsumen terhadap perusahaan yang membuat suatu barang atau jasa.

2) Citra pemakai (user image), yaitu sekumpulan asosiasi yang dipersepsikan konsumen terhadap pemakai yang menggunakan suatu barang atau jasa.

3) Citra produk (product image), yaitu sekumpulan asosiasi yang dipersepsikan konsumen terhadap suatu barang atau jasa.

\section{Faktor-Faktor Yang Membentuk Citra Merek}

Schiffman dan Kanuk dalam Farrah (2005) menyebutkan faktor-faktor pembentuk citra merek adalah sebagai berikut: 
1) Kualitas atau mutu, berkaitan dengan kualitas produk barang yang ditawarkan oleh produsen dengan merek tertentu.

2) Dapat dipercaya atau diandalkan, berkaitan dengan pendapat atau kesepakatan yang dibentuk oleh masyarakat tentang suatu produk yang dikomsumsi.

3) Kegunaan atau manfaat, yang terkait dengan fungsi dari suatu produk barang yang bisa dimanfaatkan oleh konsumen.

4) Pelayanan yang berkaitan dengan tugas produsen dalam melayani konsumennya.

5) Resiko, berkaitan dengan besar kecilnya akibat atau untung dan rugi yang mungkin dialami oleh konsumen.

6) Harga, dalam hal ini berkaitan dengan tinggi rendahnya atau banyak sedikitnya jumlah uang yang dikeluarkan konsumen untuk mempengaruhi suatu produk, juga dapat mempengaruhi citra jangka panjang.

7) Citra yang dimiliki oleh merek itu sendiri, yaitu berupa pandangan, kesepakatan dan informasi yang berkaitan dengan suatu merek dari produk tertentu.

\section{Komponen Citra Merek}

Menurut Hogan dalam Ratri (2007, p. 52), citra merek merupakan asosiasi dari semua informasi yang tersedia mengenai produk, jasa dan perusahaan dari merek yang dimaksud. Informasi ini didapat dari dua cara; yang pertama melalui pengalaman konsumen secara langsung, yang terdiri dari kepuasan fungsional dan kepuasan emosional. Merek tersebut tidak cuma dapat bekerja maksimal dan memberikan performansi yang dijanjikan tapi juga harus dapat memahami kebutuhan konsumen, mengusung nilai-nilai yang diinginkan oleh konsumen dan juga memenuhi kebutuhan individual konsumen yang akan mengkontribusi atas hubungan dengan merek tersebut. Kedua, persepsi yang dibentuk oleh perusahaan dari merek tersebut melalui berbagai macam bentuk komunikasi, seperti iklan, promosi, hubungan masyarakat (public relations), logo, fasilitas retail, sikap karyawan dalam melayani penjualan, dan performa pelayanan. Bagi banyak merek, media, dan lingkungan dimana merek tersebut dijual dapat mengkomunikasikan atribut-atribut yang berbeda. Setiap alat pencitraan ini dapat berperan dalam membina hubungan dengan konsumen. Penting demi kesuksesan sebuah merek, jika semua faktor ini dapat berjalan sejajar atau seimbang, ketika nantinya akan membentuk gambaran total dari merek tersebut. Gambaran inilah yang disebut citra merek atau reputasi merek, dan citra ini bisa berupa citra yang positif atau negatif atau bahkan diantaranya. Citra merek terdiri dari atribut objektif/instrinsik seperti ukuran kemasan dan bahan dasar yang digunakan, serta kepercayaan, perasaan, dan asosiasi yang ditimbulkan oleh merek produk tersebut. Arnould, Price, dan Ziakan dalam Ratri (2007, p. 54).

Menurut Plummer dalam Ratri (2007, p. 54), citra merek terdiri dari tiga komponen, yaitu:

1. Product attributes (Atribut produk) yang merupakan hal-hal yang berkaitan dengan merek tersebut sendiri, seperti kemasan, isi produk, harga, rasa, dan lain-lain.

2. Consumer benefits (Keuntungan konsumen) yang merupakan kegunaan produk dari merek tersebut.

3. Brand personality (Kepribadian merek) merupakan asosiasi yang mengenai kepribadian sebuah merek apabila merek tersebut adalah manusia.

\section{Pengukur Citra Merek}

Menurut (Kotler \& Keller, 2009, p. 78)

a) Kekuatan (Strengthness)

Keunggulan yang dimiliki oleh merek yang bersifat fisik dan tidak ditemukan pada merek lainnya. Keunggulan merek ini mengacu pada atribut-atribut fisik atas merek tersebut sehingga bisa dianggap sebagai sebuah kelebihan dibanding dengan merek lainnya. Yang termasuk pada sekelompok kekuatan (strength) adalah keberfungsian semua fasilitas produk, penampilan fisik, harga produk, maupun penampilan fasilitas pendukung dari produk tersebut dan memiliki cakupan pasar yang luas.

b) Keunikan (Uniqueness) 
Adalah kemampuan untuk membedakan sebuah merek diantara merek lainnya. Kesan ini muncul dari atribut produk tersebut yang menjadi bahan pembeda atau diferensiasi dengan produk-produk lainnya. Yang termasuk dalam kelompok unik ini adalah variasi penampilan atau nama dari sebuah merek yang mudah diingat dan diucapkan, dan fisik produk itu sendiri.

c) Keunggulan (Favorable)

Yang termasuk dalam kelompok favorable ini antara lain, kemudahan merek produk diucapkan serta kemampuan merek untuk tetap diingat oleh pelanggan yang membuat produk terkenal dan menjadi favorit di masyarakat maupun kesesuaian antara kesan merek di benak pelanggan dengan citra yang diinginkan perusahaan atas merek yang bersangkutan.

\section{Pengertian Kualitas Layanan}

Kualitas layanan merupakan dasar bagi pemasar jasa, karena inti produk yang dipasarkan adalah suatu kinerja yang berkualitas dan kinerjalah yang dibeli oleh konsumen. (Tjiptono \& Chandra, 2012, p. 74) kualitas layanan mencerminkan perbandingan antara tingkat layanan yang disampaikan perusahaan dibandingkan ekspektasi pelanggan. Kualitas layanan diwujudkan melalui pemenuhan kebutuhan dan keinginan pelanggan serta ketepatan penyampaian dalam mengimbangi atau melampaui harapan pelanggan. Menurut Kotler dan Keller (2009a, p. 143) "Kualitas (quality) adalah total fitur dan karakteristik produk atau jasa yang bergantung pada kemampuannya untuk memuaskan kebutuhan yang dinyatakan atau tersirat".

\section{Tujuan Dan Fungsi Pelayanan}

Kualitas pelayanan diberikan kepada konsumen harus berfungsi untuk lebih memberikan kepuasan yang maksimal, oleh karena itu dalam rangka memberikan pelayanan harus dilakukan sesuai dengan fungsi pelayanan. Kualitas pelayanan yang diberikan oleh setiap perusahaan tentunya mempunyai tujuan. Umumnya tujuan dengan diadakannya pelayanan adalah agar konsumen merasakan adanya kepuasan dan dampaknya bagi perusahaan akan memperoleh laba maksimum.

Berbisnis online, kualitas pelayanan berbeda dengan pelayanan di toko offline yang berada di dalam gerai. Barang yang diperjual belikan juga tidak dapat diraba secara langsung sehingga dibutuhkan pelayanan yang baik yang dapat menimbulkan kepercayaan yang tinggi. Menampilkan barang yang akan dijual, lakukan pemotretan memakai kamera dengan resolusi tinggi, sehingga hasilnya memuaskan. Pembeli akan tertarik karena detail barang yang jelas disertai keterangan jelas tentang barang tersebut meliputi harga, ukuran, jumlah, dan semua informasi yang akan meyakinkan pembeli. Kepercayaan yang diberikan konsumen kepada produsen harus dijaga dengan baik karena kredibilitass produsen sangat dipertaruhkan disini. Produsen harus menjaga nama baik, tepat waktu dalam pengiriman, sifat ramah, ramah dalam membalas atau merespon pesan yang dikirim oleh konsumen serta barang yang dijanjikan haruslah sama dalam (Ari \&Luthfiana, 2014).

\section{Dimensi Kualitas Layanan}

\section{a. Tangible (Bukti fisik)}

Tangible (bukti fisik) meliputi fasilitas fisik, perlengkapan, pegawai, dan sarana komunikasi (Tjiptono, 2006, p. 273), sedangkan Menurut (Lopiyoadi \& Hamdani, 2006, p. 182), Berwujud (tangible) yaitu kemampuan suatu perusahaan dalam mnunjukkan eksistensinya kepada pihak eksternal. Penampilan dan kemampuan sarana dan prasarana fisik perusahaan yang dapat diandalkan keadaan lingkungan sekitarnya merupakan bukti nyata dari pelayanan yang diberikan oleh pemberi jasa.

b. Responsiveness (Daya Tanggap)

Daya tanggap (responsiveness), yakni keinginan para staf untuk membantu para pelanggan dan memberikan layanan dengan tanggap (Tjiptono, 2006, p. 273), sedangkan menurut Lopiyoadi (2006:182), ketanggapan (responsiveness), yaitu suatu kebijakan untuk membantu dan memberikan 
pelayanan yang cepat (reponsif) dan tepat kepada pelanggan, dengan penyampaian informasi yang jelas.

c. Reliability (Kehandalan)

Reliabilitas, yakni kemampuan memberikan layanan yang dijanjikan dengan segera, akurat, dan memuaskan (Tjiptono, 2006, p. 273), sedangkan menurut Lupiyoadi (2006:182) Keandalan, kemampuan perusahaan untuk memberikan pelayanan sesuai dengan yang dijanjikan secara akurat dan terpercaya.

d. Assurance (Jaminan)

Tjiptono (2006: 273) mengemukakan bahwa jaminan mencakup pengetahuan, kompetensi, kesopanan, dan sifat dapat dipercaya yang dimiliki para staf, bebas dari bahaya, risiko atau keraguraguan, sedangkan menurut Lupiyoadi (2006:182) jaminan dan kepastian, pengetahuan, kesopansantuan, dan kemampuan para pegawai perusahaan untuk menumbuhkan rasa percaya para pelanggan kepada perusahaan.

e. Empathy (Empati)

Empati meliputi kemudahan dalam menjalin relasi, komunikasi yang baik, perhatian pribadi, dan pemahaman atas kebutuhan individual para pelanggan (Tjiptono, 2006: 273), sedangkan menurut Lupiyoadi (2006:182) empati yaitu memberikan perhatian yang tulus dan bersifat individual atau pribadi yang diberikan kepada para pelanggan dengan berupaya memahami keinginan konsumen.

\section{Pengertian Kepuasan Pelanggan}

Menurut (Kotler \& Keller, 2009a, p. 138) kepuasan pelanggan adalah perasaan senang atau kecewa seseorang yang muncul setelah membandingkan antara harapan terhadap kenyataan yang diperoleh. Kepuasan atau rasa senang yang tinggi menciptakan ikatan emosional dengan merek atau perusahaan yang bersangkutan.

Menurut (Zeithaml, Bitner, \& Gremler, 2006, p. 110), juga menyatakan bahwa "satisfaction is the consumer's fulfillment response. It is a judgement that the product or service feature, or the product or service itself, provides a pleasurable level of consumption-related fulfillment". Artinya, kepuasan merupakan respon pemenuhan dari konsumen, hal ini merupakan penilaian mengenai bentuk dari produk dan layanan, atau mengenai produk atau layanan itu sendiri, dalam menyediakan tingkat kepuasan dari konsumsi yang terpenuhi.

Definisi di atas ini dapat dirumuskan sebagai berikut:

\section{Kepuasan Pelanggan $=\mathbf{f}($ Harapan, kinerja $)$}

Kotler and Keller dalam Fandy Tjiptono (2014, p. 369) Ada empat metode yang sering digunakan dalam mengukur kepuasan pelanggan:

1) Sistem keluhan dan saran

2) Ghost Shopping

3) Lost Costumer analysis

4) Survei Kepuasan pelanggan

\section{Faktor-faktor yang mempengaruhi Kepuasaan Pelanggan}

Menurut (Lopiyoadi, 2001, p. 158) menyebutkan lima faktor utama yang perlu diperhatikan dalam kaitannya dengan kepuasan konsumen, antara lain:

a. Kualitas Produk

Konsumen akan puas bila hasil evaluasi mereka menunjukkan bahwa produk yang mereka gunakan berkualitas. Produk dikatakan berkualitas bagi seseorang, jika produk itu dapat memenuhi kebutuhanya, Kualitas produk ada dua yaitu eksternal dan internal. Salah satu kualitas produk dari faktor eksternal adalah citra merek.

b. Kualitas Pelayanan 
Konsumen akan merasa puas bila mendapatkan pelayanan yang baik atau yang sesuai dengan harapan.

c. Emosional

Konsumen merasa puas ketika orang memuji dia karena menggunakan merek yang mahal.

d. Harga

Produk yang mempunyai kualitas yang sama tetapi menetapkan harga yang relatif murah akan memberikan nilai yang lebih tinggi.

e. Biaya

Konsumen yang tidak perlu mengeluarkan biaya tambahan atau tidak perlu membuang waktu untuk mendapatkan suatu produk atau jasa cenderung puas terhadap produk atau jasa tersebut.

\section{Komponen Kepuasan Pelanggan}

Seperti yang telah dikemukakan di atas bahwa ada banyak pengertian kepuasan pelanggan. Menurut (Giese \& Cote, 2002) sekalipun banyak definisi kepuasan pelanggan namun secara umum tetap mengarah kepada tiga komponen utama, yaitu:

a) Respon : Tipe dan intensitas

Kepuasan pelanggan merupakan respon emosional dan juga kognitif. Intesitas responnya mulai dari sangat puas dan menyukai produk sampai sikap yang apatis terhadap produk tertentu.

b) Fokus

Fokus pada performansi objek disesuaikan pada beberapa standar. Nilai standar ini secara langsung berhubungan dengan produk, konsumsi, keputusan berbelanja, penjual dan toko.

c) Waktu respon

Respon terjadi pada waktu tertentu, antara lain: setelah konsumsi, setelah pemilihan produk atau jasa, berdasarkan pengalaman akumulatif. Durasi kepuasan mengarah kepada berapa lama respon kepuasan itu berakhir.

\section{Pengertian Loyalitas Pelanggan}

Oliver dalam Hurryati (2010, p. 128) mengungkapkan loyalitas pelanggan adalah komitmen pelanggan bertahan secara mendalam untuk berlangganan kembali atau melakukan pembelian ulang produk atau jasa terpilih secara konsisten dimasa yang akan datang, meskipun pengaruh situasi dan usaha-usaha pemasaran mempunyai potensi untuk menyebabkan perubahan perilaku. Menurut Griffin (2005) loyalitas dapat didefinisikan berdasarkan perilaku membeli. Konsumen yang loyal adalah orang yang melakukan pembelian berulang produk atau jasa secara teratur, membeli antar lini produk atau jasa, mereferensikan kepada orang lain dan menunjukkan kekebalan terhadap tarikan dari perusahaan lain.

\section{Pengukuran Loyalitas}

Menurut (Griffin, 2005, p. 31) loyalitas pelanggan tampaknya merupakan ukuran yang lebih dapat diandalkan untuk memprediksi pertumbuhan penjualan dan keuangan. Berbeda dari kepuasan yang merupakan sikap, loyalitas dapat didefinisikan berdasarkan perilaku membeli. Pelanggan yang loyal adalah orang yang:

1. Melakukan pembelian berulang secara teratur. Pelanggan yang loyal adalah mereka yang melakukan pembelian barang ataupun jasa secara teratur bahkan mereka akan tetap membeli meskipun harganya mengalami kenaikan.

2. Membeli antar lini produk dan jasa. Pelanggan yang loyal bukan hanya membeli satu jenis produk atau jasa saja dari sebuah perusahaan, melainkan mereka juga membeli produk ataupun jasa tambahan yang disediakan oleh perusahaan tersebut.

3. Mereferensikan kepada orang lain. Pelanggan yang loyal selalu ingin mereferensikan suatu produk atau jasa yang digunakannya kepada orang lain, baik kepada teman maupun saudara. Mereka selalu berusaha mempengaruhi orang lain untuk menggunakan produk atau jasa yang sama dengan selalu 
menceritakan kelebihan produk atau jasa yang dia gunakan sampai orang tersebut mencoba menggunakannya.

4. Menunjukkan kekebalan terhadap tarikan dari pesaing. Para pelanggan yang loyal selalu menolak apabila ditawari produk atau jasa dari perusahaan lain (pesaing). Mereka sudah memiliki kecintaan tersendiri terhadap produk atau jasa yang telah digunakan.

\section{Kerangka Pemikiran}

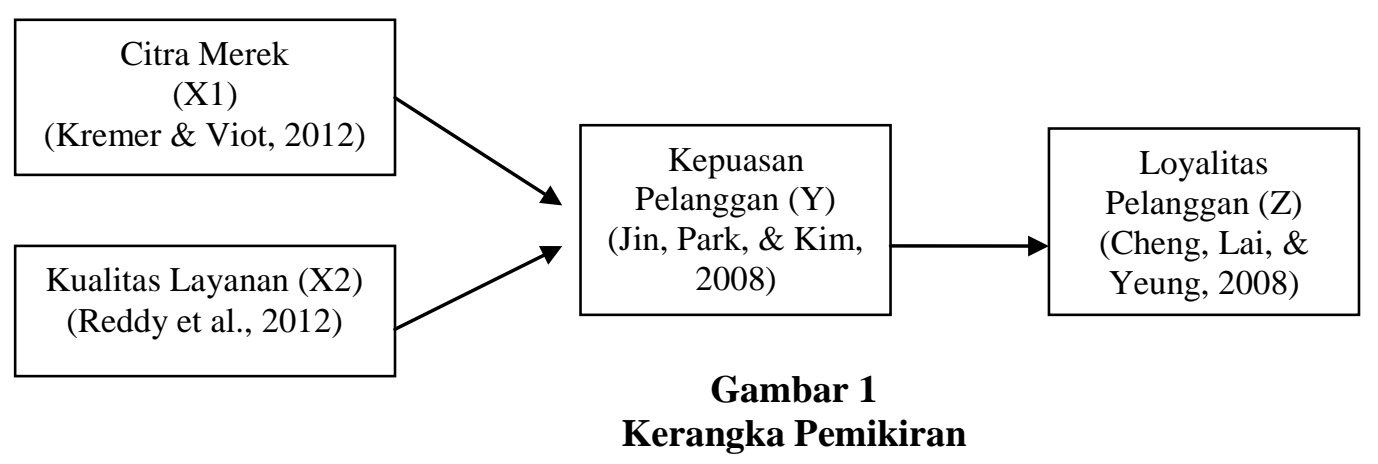

Teori dan kerangka berpikir diatas dapat disusun beberapa hipotesis sebagai berikut:

1 Citra Merek berpengaruh signifikan terhadap Kepuasan Pelanggan 3Second di Kota Palu.

2 Kualitas Layanan berpengaruh signifikan terhadap Kepuasan Pelanggan 3Second di Kota Palu.

3 Kepuasan Pelanggan berpengaruh signifikan terhadap Loyalitas Pelanggan 3Second di Kota Palu.

\section{METODE PENELITIAN}

Penelitian ini merupakan jenis penelitian kausal dimana ditujukan untuk menganalisis hubungan sebab akibat antar variabel yaitu variabel-variabel citra merek, kualitas layanan sebagai variabel bebas dan kepuasan serta loyalitas pelanggan sebagai variabel terikat. Sebagaimana dikemukakan oleh Sugiyono (2014a, p. 54) bahwa penelitian deskriptif adalah metode yang digunakan untuk menganalisa data dengan cara mendeskripsikan atau menggambarkan data yang telah terkumpul sebagaimana adanya tanpa bermaksud membuat kesimpulan yang berlaku untuk umum atau generalisasi. Teknik pengambilan dan pengumpulan data yang dilakukan dengan cara: observasi, wawancara, kuesioner, dan dokumentasi. Populasi dalam penelitian ini adalah para pelanggan yang telah menggunakan produk 3Second di Kota Palu. Teknik pengambilan sampel untuk menentukan sampel yang akan digunakan dalam penelitian ini menggunakan Teknik non probability sampling, yaitu purposive sampling. Dikarenakan jumlah populasinya tidak diketahui secara pasti maka untuk menentukan besarnya sampel yaitu dengan menggunakan rumus Unknown Populations Frendy dalam Ekasari (2014: 98)

$$
\mathrm{n}=\frac{\mathrm{Z}^{2}}{4 \mu^{2}}
$$

Keterangan:

$\mathrm{n}=$ ukuran sampel

$\mathrm{Z}=$ tingkat keyakinan sampel yang dibutuhkan dalam penelitian, pada $\alpha=5 \%$ (derajat keyakinan ditentukan 95\%) maka $\mathrm{Z}=1,96$

$\mu=$ margin of error, tingkat kesalahan yang dapat ditolerir (ditentukan 10\%)

Menggunakan rumus diatas, maka diperoleh perhitungan sebagai berikut:

$\mathrm{n}=\frac{1,96^{2}}{4(0,1)^{2}}$

$\mathrm{n}=96,4 \approx 100$ responden 


\section{Analisis Jalur}

Riduwan dan Kuncoro (2007:2) model analisis jalur (path analysis) digunakan untuk menganalisis pola hubungan antarvariabel dengan tujuan untuk mengetahui pengaruh langsung maupun tidak langsung seperangkat variabel bebas (eksogen) terhadap variabel terikat (endogen).

persamaan struktural dalam model analisis jalur ini adalah sebagai berikut:

$\mathrm{Y}=\rho \mathrm{yx}_{1}+\rho \mathrm{yx}_{2}+\epsilon_{1}$

$Z=\rho z y+\epsilon_{2}$

\section{HASIL DAN PEMBAHASAN}

Analisis Jalur ( Path Analysis )

Tabel 2

Hasil Regresi Persamaan Struktural Pertama

\begin{tabular}{|l|c|c|c|c|c|}
\hline \multirow{2}{*}{ Model } & \multicolumn{2}{|l|}{$\begin{array}{l}\text { Unstandardized } \\
\text { Coefficients }\end{array}$} & $\begin{array}{l}\text { Standardized } \\
\text { Coefficients }\end{array}$ & \multirow{2}{*}{$\mathrm{T}$} & \multirow{2}{*}{ Sig. } \\
\cline { 2 - 6 } & $\mathrm{B}$ & Std.Error & Beta & & \\
\hline Citra Merek (X1) & 0.347 & 0.103 & 0.273 & 3.366 & 0.001 \\
\hline Kualitas Layanan (X2) & 0.649 & 0.103 & 0.511 & 6.301 & 0.000 \\
\hline $\mathrm{R}=0,646$ & & & \\
R Square $=0,417$ & & & \\
Adjusted R Square $=0,405$ \\
Dependent Variabel: Kepuasan Pelanggan (Y)
\end{tabular}

Sumber: Data primer diolah

Pengaruh kesalahan pengganggu atau error variabel $\left(\rho \varepsilon_{1}\right)$ untuk persamaan struktural pertama diperoleh:

$P \mathcal{E} 1=\sqrt{1-(R)^{2}}$

$\sqrt{1}-0,646$

$=0,763$

Persamaan struktural pertama diperoleh:

$Y=0,273 X 1+0,511 \times 2+0,763 \varepsilon_{1}$

Persamaan struktural tersebut menunjukan bahwa nilai koefisien berpengaruh Citra merek (X1) terhadap kepuasan pelanggan (Y) sebesar 0,273. Kualitas layanan (X2) terhadap kepuasan pelanggan (Y) sebesar 0,511.

Persamaan struktural kedua:

$Z=\boldsymbol{\rho z y} \mathbf{Y}+\epsilon_{2}$

Hasil analisis regresi untuk persamaan struktural kedua disajikan pada tabel berikut ini:

Tabel 3

Hasil Regresi Persamaan Struktural Kedua

\begin{tabular}{|l|c|c|c|c|c|}
\hline \multirow{2}{*}{ Model } & \multicolumn{2}{|c|}{$\begin{array}{c}\text { Unstandardized } \\
\text { Coefficients }\end{array}$} & $\begin{array}{l}\text { Standardized } \\
\text { Coefficients }\end{array}$ & \multirow{2}{*}{ T } & \multirow{2}{*}{ Sig. } \\
\cline { 2 - 6 } & $\mathrm{B}$ & Std.Error & Beta & & \\
\hline Kepuasan pelanggan (Y) & 0.581 & 0.070 & 0.644 & 8.337 & 0.000 \\
\hline $\mathrm{R}$ & $=0,644$ & & \\
R Square $=0,415$ & & & \\
Adjusted R Square $=0,409$ & & & \\
Dependent Variabel: Loyalitas Pelanggan (Z)
\end{tabular}


Pengaruh kesalahan pengganggu atau error variabel $\left(\rho \varepsilon_{2}\right)$ untuk persamaan struktural kedua diperoleh:

$$
\begin{aligned}
\mathrm{P} \mathcal{E}_{2} & =\sqrt{1-R^{2}} \\
& \sqrt{1}-0,644 \\
& =0,765
\end{aligned}
$$

Persamaan struktural kedua diperoleh:

$$
Z=-0.644 Y+0,765 \varepsilon_{2}
$$

Persamaan struktural tersebut menunjukan bahwa nilai koefisien berpengruh Kepuasan pelanggan (Y) terhadap Loyalitas pelanggan (Z) sebesar 0,644 yang berarti apabila kepuasan pelanggan (Y) meningkat satu satuan maka Loyalitas pelanggan (Z) akan meningkat 0,644 satuan.

\section{Pembahasan}

1) Tinggi rendahnya kepuasan pelanggan $(Y)$ dipengaruhi oleh citra merek (X1). Besarnya pengaruh citra merek $(\mathrm{X})$ terhadap kepuasan pelanggan $(\mathrm{Y})$ sebesar 0,273 atau sebesar $(0,273)^{2} \times 100 \%=$ 7,453\% Jadi, citra merek (X1) berpengaruh terhadap kepuasan pelanggan (Y) sebesar 7,453\%.

2) Pengaruh kualitas Layanan (X2) terhadap kepuasan pelanggan $(Y)$ sebesar 0,511. Berdasarkan koefisien pengaruh tersebut dapat dinyatakan bahwa naik turunnya kepuasan pelanggan ditentukan oleh kualitas layanan adalah sebesar $26,11 \%$, yang dipeoleh dari rumus $(0,511)^{2} \times 100 \%=$ $26,11 \%$.

3) Loyalitas pelanggan (Z) ditentukan oleh kepuasan pelanggan (Y) sebesar 0,644. Berdasarkan koefisen pengaruh tersebut dapat dinyatakan bahwa naik turunnya kepuasan pelanggan di tentukan oleh loyalitas pelanggan adalah sebesar $41,47 \%$ yang diperoleh dari rumus $(0,644)^{2}$ x $100 \%=$ $41,47 \%$

\section{KESIMPULAN DAN SARAN}

\section{Kesimpulan}

1. Citra Merek memiliki pengaruh dalam meningkatkan Kepuasan Pelanggan pada gerai 3Ssecond di Kota Palu.

2. Kualitas layanan memiliki peran dalam menentukan Kepuasan Pelanggan pada gerai 3Second di Kota Palu.

3. Terdapat pengaruh Kepuasan Pelanggan terhadap Loyalitas Pelanggan gerai 3Second di Kota Palu.

4. Secara bersama-sama variabel Citra Merek, Kualitas Layanan, dan Kepuasan Pelanggan memiliki peran dalam meningkatkan Loyalitas Pelanggan.

\section{Saran}

1. Bagi perusahaan

a. Disarankan pada 3Second di Kota Palu untuk memperkuat citra merek dengan cara meningkatkan kepedulian perusahaan terhadap kepentingan pelanggan, dan suasana yang nyaman dari sebuah toko atau gerai fashion menjadi salah satu nilai tambah yang akan mengundang pelanggan dan calon pelanggan untuk mau mengunjungi dan melakukan pembelian di toko atau gerai tersebut. Selain itu untuk meningkatkan citra merek maka perusahaan harus tetap menawarkan produk-produk berkualitas.

b. 3Second di Kota Palu sebaiknya memperkuat kualitas layanan dengan memberikan pelayanan yang ramah, meningkatkan keeratan hubungan dengan pelanggan. karyawan 3Second juga sebaiknya meningkatkan perhatian kepada pelanggan serta meningkatkan kepercayaan yang tinggi kepada pelanggan melalui layanannya. Kualitas layanan yang semakin baik harus dilakukan dalam upaya untuk memberikan rasa puas kepada pelanggan 3Second. 
c. Peneliti menyarankan pada 3Second untuk meningkatkan loyalitas pelanggan, maka perusahaan harus mampu meningkatkan kepuasan pelanggannya. Sementara kepuasan pelanggan sendiri hanya dapat diperoleh dengan memberikan citra yang baik dan kualitas layanan prima bagi pelanggan.

2. Bagi peneliti selanjutnya

Bagi peneliti selanjutnya yang ingin meneliti atau melanjutkan penelitian ini, disarankan untuk meneruskan atau mengembangkan penelitian ini dengan mencari faktor lain yang dapat mempengaruhi loyalitas pelanggan dan kepuasan pelanggan. Perluasan penelitian juga dapat dilakukan dengan meningkatkan jumlah sampel dan penarikan sampel secara probabilitas.

\section{REFERENSI}

Ari, \& Luthfiana, (2014). Pengaruh Citra Merek Dan Kualitas Produk dengan Kepuasan Konsumen Sebagai A. Variabel Antara Terhadap Loyalitas Konsumen Air Minum Merek Aqua. Jurnal Ilmu Administrasi Bisnis.

Ekasari, Novita. (2014). Pengaruh Promosi berbasis Social media terhadap

keputusan pembelian produk jasa Pembiayaan kendaraan PT.BFI Finance Jambi. Jurnal Penelitian Seri Humaniora, Vol.16, No.2, Hal. 81-102. ISSN: 0852-8349. Universitas Jambi.

Farrah, F. Z. (2005). Strategi Perluasan Merek dan Loyalitas Konsumen. Jurnal Insan, vol.7, No.3, Hal. 267-288.

Giese, \& Cote. (2002). Defining Consumer Satisfaction. Academy of Marketing Science Review, 20(2), 1.

Griffin, R. W. (2005). Metodologi Penelitian Bisnis: Salah Kaprah Dan Pengalaman-Pengalaman. Jakarta: Erlangga.

Hurryati, R. (2010). Bauran Pemasaran dan Loyalitas Konsumen. Bandung: Alfabeta.

Irawan, H. (2008). Indonesia Customer Satisfaction. Jakarta: PT. Alex Media Computindo.

Kotler, P. (2009). Manajemen Pemasaran (11th ed.). Jakarta: Indeks kelompok. Gramedia.

Kotler, P., \& Keller, K. L. (2009). Manajemen Pemasaran Jilid 1 (13th ed.). Jakarta: Erlangga.

Kotler, P., \& Keller, K. L. (2009). Manajemen Pemasaran Jilid 2 (13th ed.). Jakarta: Erlangga.

Lopiyoadi, R. (2001). Manajemen Pemasaran Jasa: Teori dan Praktik (Pertama). Jakarta: Salemba Empat.

Lopiyoadi, R. D. A., \& Hamdani. (2006). Manajemen Pemasaran Jasa (12th ed.). Jakarta: Salemba Empat.

Ratri, L. E. (2007). Hubungan Antara Citra Merek (Brand Image) Operator Seluler dengan Loyalitas Merek (Brand Loyalty) Pada Mahasiswa Pengguna Telepon Seluler di Fakultas Ekonomi Reguler Universitas Diponegoro Semarang. Universitas Diponegoro, Semarang.

Riduwan, \& Kuncoro. (2007). Cara menggunakan dan memaknai Analisis Jalur. Bandung: Alfabeta.

Sangadji, M. ., \& Shopiah. (2013). Perilaku Konsumen Pendekatan Praktis Disertai: Himpunan Jurnal Penelitian. Yogyakarta: CV Andi Offset.

Sugiyono. (2014). Metode Penelitian Manajemen: Pendekatan Kuantitatif, Kualitatif, Kombinasi, Penelitian tindakan dan Penelitian Evaluasi (3rd ed.). Bandung: Alfabeta.

Sugiyono. (2014). Statistika Untuk Penelitian. Bandung: Alfabeta.

Sulistian, ogi. (2011). Pengaruh Brand Image Terhadap Loyalitas Pelanggan Rokok Gudang Garam Filte. Universitas Kuningan, Kuningan.

Suprapti, S. (2010). Perilaku Kosumen. Udayana University Press.

Tjiptono, F. (2006). Pemasaran Jasa. Malang: Bayumedia.

Tjiptono, F. (2014). Pemasaran Jasa. Prinsip, penerapan, penelitian. Yogyakarta: Andi Offset.

Tjiptono, F., \& Chandra, G. (2012). Pemasaran Strategik. Yogyakarta: Andi Offset.

Zeithaml, V. A., Bitner, M. J., \& Gremler. (2006). Services Marketing (4th ed.). New York: Mc GrawHill. 